${ }^{\odot}$ Entomologica Fennica. 29.III.1993

\title{
New finds of Ephedrus and Toxares species (Hymenoptera, Braconidae, Aphidiinae) from Finland
}

\author{
Martti Koponen \& Jussi Halme
}

Koponen, M. \& Halme, J. 1993: New finds of Ephedrus and Toxares species (Hymenoptera, Braconidae, Aphidiinae) from Finland. - Entomol. Fennica 4:31-36.

Fourteen species of Ephedrus and one of Toxares have been recognized from Finland. Their distribution is presented in UTM-maps, and new provincial records are listed. The taxonomy, diagnosis and biology of some species is discussed. New species for Finland are Ephedrus chaitophori Gärdenfors, E. longistigmus Gärdenfors and E. vaccinii Gärdenfors.

Martti Koponen, Department of Applied Zoology, P.O. Box 27 (Viikki C), FIN-00014 University of Helsinki, Finland

Jussi Halme, Keltakankaantie 31, FIN-46860 Anjalankoski, Finland

\section{Introduction}

A review of the study of Aphidiidae of Finland was published by Halme in 1977. Although this group has often been considered a separate family, there is now virtually universal agreement among braconid workers that it constitutes a specialized group of Braconidae (van Achterberg 1990). Mainly with the aid of a recent revision of the genus Ephedrus (Gärdenfors 1986), we have determined Finnish material of this genus and Toxares. One species new to science (Halme 1992) and three species new for Finland were found, and several new provincial records were made. The purpose of this article is to list the 15 Finnish species, present their distribution in Finland in UTM-maps (Fig. 3), and give more detailed faunistic information regarding the most interesting species. The taxonomy, diagnosis and biology of some of the species are also discussed.

\section{Material}

Most of the material (about 700 specimens) was collected by sweeping by M. Koponen and is in the Department of Applied Zoology, University of Helsinki (abbreviated DAZH). Most of the reared material was collected by J. Halme and is in his collection. Some specimens in the Zoological Museum, University of Helsinki (MZH) have been investigated, and at least some of the hosts have been determined by $\mathrm{Mr}$. O. Heikinheimo. The host names follow Huldén \& Heikinheimo 1984. Abbreviations of collector names are $\mathrm{JH}=\mathrm{J}$. Halme, $\mathrm{MK}=\mathrm{M}$. Koponen, $\mathrm{OH}=\mathrm{O}$. Heikinheimo, $\mathrm{YZ}=$ Yang Zhongqi. 


\section{The Finnish species of Ephedrus and Toxares}

Ephedrus (Breviephedrus) brevis Stelfox, 1941

Ephedrus picticornis Stelfox, 1941

Material: Reported by Mackauer (1968) from province $T b$ (Keuruu). New material is from $N$ : Helsinki (668:38, 668:39), Nurmijärvi (671:37); St: Eura (677:23), Loimaa rural mun. (676:29), Säkylä (676:244), Yläne (675:24), (676:25); Ta: Janakkala (676:38), Jokioinen (675:30); Sa: Ristiina (682:50); Om: Kalajoki (713:35), Pyhäntä (711:46), Vimpeli (700:34); Ok: Vaala (716:50); Ob: Pudasjärvi (728:48), Tervola (734:39); $L i$ : Inari (7615:517).

Based on the combinations of characters in our 17 female specimens we agree with Gärdenfors (1986) that E. brevis is a widely variable species consisting of specimens similar to the original types of E. brevis and E. picticornis.

\section{Ephedrus (Ephedrus) cerasicola Starý, 1962}

Material: Known specimens from Finland are from $N$ : Helsinki (6680:390) 15.5.1980 1 ○ (MK), Nurmijärvi (6715:376) 5.8.1979 $1 \mathrm{O}^{7}$ (MK), Vantaa (6688:392) 8.5.1948 (OH); Sa: Kouvola (675:48) 7.7.1980 5 oᄋ (JH), Valkeala (6782:507) 21.6.1975 (JH leg.).

The specimen reported (Peltonen 1976) as cerasicola from Sa: Taipalsaari is E. validus (det. Halme 1984) and from N: Vantaa 21.6.1952 ex Hyperomyzus lactucae (Linnaeus) (Halme 1977) is E. lacertosus (Haliday) (det. Gärdenfors 1984).

\section{Ephedrus (Ephedrus) chaitophori Gärdenfors, 1986}

Material: From Finland, 5 males and 6 females have been determined. $N$ : Helsinki (6682:383) 26.6.1980 $1 \mathrm{O}^{7}$ (MK); Ta: Kuusankoski (675:48) 4.8.1982 4 ơ 4 오 (JH), Lammi (6777:392) 23.8.1981 1 ㅇ (MK) and Om: Kokkola (7088:312) 17.8.1982 1 ф (MK leg.).

New to Finland. For further distribution, see Gärdenfors (1986).

\section{Ephedrus (Ephedrus) helleni Mackauer, 1968}

Material: The female type and female paratype (in MZH) are from Finland, N: Helsinki (Mackauer 1968, Gärdenfors 1986). Reported by Mackauer (1968) also from province $L i$ (Ivalo). 4 o $^{\top}{ }^{\top} 20$ oO have been determined from $N$ : Helsinki (6678:398, 668:38, 668:39), Nurmijärvi (671:37); Ta: Hämeenlinna (6771:361), Lammi (677:39);
Sa: Mikkeli rural mun. (6830:501, 6859:513), Ristiina (6826:502); Kl: Uukuniemi (6862:655); Oa: Kurikka (6945:267); $S b$ : Joroinen (690:54); Om: Himanka (7111:337), Kalajoki (7134:352); Ks: Kuusamo (7366:603).

\section{Ephedrus (Ephedrus) koponeni Halme, 1992}

This new species is described and discussed by Halme (1992). It is thus far known only from Finland.

Ephedrus (Ephedrus) lacertosus (Haliday, 1833)

The only species which has been collected from every province of Finland.

Ephedrus (Ephedrus) laevicollis (Thomson, 1895)

Ephedrus plagiator var. minor Stelfox, 1941 (Gärdenfors 1986).

Ephedrus minor: Mackauer \& Starý 1967, Mackauer 1968, Halme 1977.

Material: Reported by Mackauer (1968) from Finland, province $N$. In our swept material there are $13 \mathrm{Ob}^{\mathrm{T}}$ and 12 우. New provincial records are $A b$ : Perniö; $T a$ : Hämeenlinna (6771:361); $S a$ : Kouvola (675:48), Mikkeli rural mun. (6830:501, 6859:513), Valkeala (674:48); Oa: Kurikka (6945:267), Lapua (698:28); Sb: Joroinen (690:54); Om: Himanka (7111:337); Ks: Kuusamo (7366:603).

\section{Ephedrus (Ephedrus) longistigmus Gärdenfors, 1986}

Material: In DAZH there are $60^{7}$ and 12 og from Finland, $A b$ : Lohja rural municipality (6693:334) 19.6.1992 1 o; $N$ : Nurmijärvi (6707:379) 31.5.1992 1 o, (6704:381) 26.6.1992 1 o, (6705:381) 28.6.1987 1 o, 30.6.1987 1 ơ, 20.6.1992 1 o, (6707:381) 6.6.1987 1 ○', (6710:377) 20.6.1987 1 ơ 1 o, (6711:377) 21.8.1987 2 क्ष , 24.7.1992 1 o, Porvoo rural mun. (6694:436) 3.6.1982 $1 \mathrm{O}^{\top}$ (MK); Sa: Joroinen (690:54) 9.8.1982 1 o (YZ), Pielavesi (7032:477) 28.6.1991 1 o'; Ok: Paltamo (713:54) 3.7.1991 2 oᄋ; $L k$ :

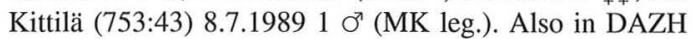
there is $1 \mathrm{O}^{\mathrm{T}}$ from Estonia, Võru: Murati, 27.5.1991 (MK leg.).

A species new to the western Palearctic. Earlier known was only the type material from Japan, Taiwan and USA (Gärdenfors 1986).

\section{Ephedrus (Ephedrus) nacheri Quilis, 1934}

Material: Reported by Gärdenfors (1986) from Finland, province $N$ (paratype of $E$. helleni Mackauer). Our swept 
and determined material is $10 \mathrm{Ob}^{\top} 25 \mathrm{OQ}$. New provincial records are $A b$ : Rymättylä (669:22); Ta: Lammi (677:39); Sa: Kouvola (675:48), Mikkeli rural mun. (6830:501), Ristiina (6826:502), Valkeala (674:48, 6772:483); Ob: Rovaniemi (734:44).

Reared from Hyperomyzus rhinanthi (Schouteden) by $\mathrm{O}$. Heikinheimo ( $N$ : Helsinki rural mun.).

Ephedrus (Ephedrus) niger Gautier, Bonnamour \& Gaumont, 1929

Ephedrus campestris Starý (Mackauer \& Starý 1967).

Material: Reported as E. campestris by Mackauer (1968) from Finland, province $N$. Our swept material is 10 $\sigma^{7} O^{7}$ and 25 oo. New provincial records are $A b$ : Perniö (669:22); Ka: Ylämaa (6740:550); Ta: Hattula (6773:361), Lammi (677:39), Ruovesi (6868:348); Sa: Kouvola (675: 48), Mikkeli rural mun. (6830:501), Valkeala (674:48); $S b$ : Kuopio (697:53); $O b$ : Ii (7249:424); $L k$ : Sodankylä (748:48); Li: Inari (7591:478, 7615:517, 7617:521).

\section{Ephedrus (Ephedrus) persicae Froggatt, 1904}

Ephedrus nitidus Gahan, 1917 (Mackauer 1963). Thuneberg 1963.

Ephedrus pulchellus Stelfox, 1941 (Mackaver 1963). Starý 1962.

Ephedrus holmani Starý, 1958 (Mackauer 1963).

Material: Reported by Thuneberg (1963) and Mackauer (1968) from Finland, provinces $A b$ (Nystad = Uusikaupunki), $\mathrm{Ka}$ (Vehkalahti, Ulkotammio), St (Karkku), Ta (Sääksmäki), $S a$ (Joutseno), and $O b$ (Rovaniemi). At least some of these reports may refer to $E$. (E.) chaitophori Gärdenfors. Our swept and determined material is $4 \mathrm{Ob}^{\mathrm{T}}$ and 15 oo. New records are $A b$ : Perniö (6682:271); $N$ : Helsinki (6682:393, 6680:390); Ta: Lammi (6773:394); Sa: Kouvola (675:48), Pertunmaa (6810:465), Valkeala (674: 48); Sb: Kuopio (697:53); Ks: Salla (7377:560); EnL: Kilpisjärvi (767:25).

All host records of this parasitoid must be reclassified owing to the similar structure of the diapause cocoon in E. persicae and Pseudopauesia prunicola Halme (Halme 1986). In E. persicae the cocoon is at first dark (Stary 1962) and probably later turns out to black-greyish (Starý 1970). In P. prunicola it is reddish brown from the very beginning and does not change coloration with age. The second author never succeeded in finding the dark diapause cocoons in southern Finland. This is quite surprising, because according to Starý (1970), in central Eu- rope they have been found in lowlands, as well as in foothills and mountains. In southern Finland some of the ordinary hosts of E. persicae (Starý 1962): Aphis idaei van der Goot on Rubus idaeus, Dysaphis sp. on Sorbus aucuparia and Rhopalosiphum padi (Linnaeus) on Prunus padus were not occupied by this parasitoid. Instead, our E. persicae were reared from Brachycaudus spp. on Silene dioica (Thuneberg 1963), S. latifolia and Spirea salicifolia (leg. J. Halme).

\section{Ephedrus (Ephedrus) plagiator (Nees, 1811)}

Material: The most common Ephedrus species found in all Finnish provinces except $K a, S b, K b$ and $O k$.

Diagnosis: The second author reared many Ephedrus parasitoids from Sitobion avenae (Fabricius) and Dysaphis sorbi (Kaltenbach). The samples included E. plagiator exclusively, with some of the largest individuals showing the colour pattern typical of E. blattnyi Starý and $E$. prociphili Starý. From among the former species these individuals were separated by means of wing venation. They have one quarter to one third of F1 yellowish, which conforms with the Nearctic population of $E$. prociphili (Gärdenfors 1986) but not with the European population of this species (Starý 1982): F1 usually prevalently yellow. Furthermore, $S$. avenae as a host does not conform with the European E. prociphili (Starý 1982): propagation impossible on $S$. avenae.

Among the largest swept $E$. plagiator-like parasitoids we found individuals fully corresponding to the redescription of E. blattnyi Starý, 1973 (Gärdenfors 1986). These individuals were not included in this paper because the distinguishing characters are not very reliable (information in letter from Dr. U. Gärdenfors 1991). In southern Finland the second author never found E. blattnyi among Ephedrus-parasitoids reared from Pterocomma spp., the hosts of the species (Starý \& Leclant 1973).

\section{Ephedrus (Ephedrus) vaccinii Gärdenfors, 1986}

Material: Records from Finland are $A b$ : Nauvo, Seili (669:22) 18.7.1978 1 o (MK); $N$ : Kirkkonummi (665:36) 9.7.1977 1 O $^{7}$ reared from Aulacorthrum flavum Börner on Vaccinium uliginosum (JH), Nurmijärvi (6715:376) 3.9.1977 1m (MK); Ta: Kuusankoski (675:48) 4.8.1982 1 ơ (JH leg.). 


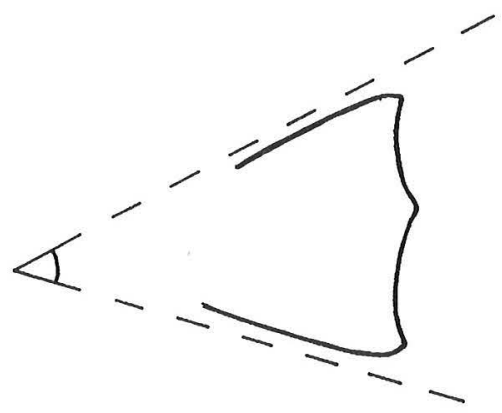

Fig. 1. Measurement of angle of ovipositor sheath of Toxares.

New to Finland. The host species was recently reported from Finland by Heikinheimo (1990). For further distribution, see Gärdenfors 1986.

Ephedrus (Lysephedrus) validus (Haliday, 1833)

Material studied in DAZH (19 $\left.900^{7} 0^{7}\right)$ is from $N$ : Anjala (673:48), Helsinki (668:39), Nurmijärvi (6709:375, 6708:380, 6715:376), Sipoo (6687:407); Ta: Hämeenlinna (6768:364), Tampere; Sa: Taipalsaari (6800:564); Tb: Rautalampi (6961:484); Sb: Pieksämäki rural mun. (6924:487); $L k$ : Kittilä (753:43), Kolari (7475:362); $L k$ : Sodankylä (7481:483); Le: Hetta (759:36); Li: Utsjoki (7753:500).

Reported by Mackauer (1968) from Finland, provinces $A b$ (Lojo = Lohja, Nystad = Uusikaupunki), $N$ (Ekenäs = Tammisaari), St (Kark$\mathrm{ku})$, Oa $($ Maxmo = Maksamaa), $\mathrm{Tb}($ Keuru = Keuruu, Pihtipudas), Li (Utsjoki).

Toxares deltiger (Haliday, 1840)

Toxares flaveolus (Györfi, 1958).

Material: Reported by Mackauer (1968) from Finland, provinces $A l, S a$ and $S b$. New provincial records are $A b$ : Västanfjärd (6669:261); $N$ : Helsinki (668:39), Nurmijärvi (6715:376), Tammisaari (6657:302), Vantaa (6688:392); Tb: Pihtipudas (7027:430), Ähtäri (6940:348); Om: Perho (7011:364); Ok: Kuhmo (710:66), Paltamo (7144:547), Puolanka (720:53), Ristijärvi (7152:554, 7164:549); Ob: Tornio (7312:385), Yli-Ii (7248:444); Ks: Kuusamo (7366:604); Lk: Kemijärvi (7395:528), Kolari (7475:362) and Sodankylä (7582:516).

The structure of Finnish individuals lies somewhere between the Central European $T$.

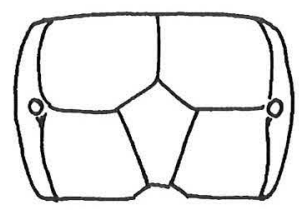

a

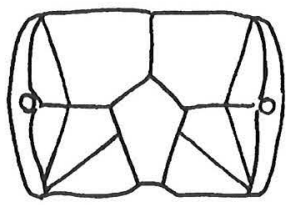

C

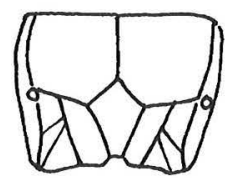

e

Fig. 2a-e. Carination patterns of propodeum of Toxares deltiger (Haliday) in Finland (a-d) and in Czechoslovakia (e, according to Starý 1958).

deltiger samples (Starý 1958) and the East Palearctic T. shigai Takada (Takada 1965). The angle of the ovipositor sheath (Fig. 1) in the type of T. shigai $\left(30^{\circ}\right)$ and in our 12 measured specimens (mean $36^{\circ}, S D 3.516$ ) does not differ significantly $(t=1.706)$. The other features, however, support the specific status of $T$. shigai. The radius index (length of second radial abscissa per length of third radial abscissa) of the type of $T$. shigai (0.825) differs from the radius indexes of our specimens (mean 0.620, SD 0.081) fairly significantly $\left(t=2.555^{*}\right)$. The petiolus index (width of petiolus at spiracles per length of petiolus) of $T$. shigai (3.3) differs from that of our Finnish specimens (mean 2.367, SD 0.285) significantly $(t=3.274 * *)$. Shuja-Uddin (1974) constructed a key which distinguishes the females of T. deltiger and T. shigai (several Indian records) on the basis of the number of antennal segments: shigai with 17 and deltiger with more than 18. In Finland deltiger has 18-20 antennal segments (18 in 6, 19 in 3 and 20 in 3 individuals). The intra-areal carination of the propodeum of $T$. deltiger is widely variable (Fig. 2: 3 individuals of type a, 6 of b, 2 of c, 1 of d, and 1 of e). In this 
respect only one of our specimens (Fig. 2d) was similar to the type (Fig. 2e) described by Starý (1958) from Central Europe.

Acknowledgements. We are indebted to Dr. Ulf Gärdenfors for critical comments on the manuscript and to Mr. O. Heikinheimo, MS, for determining host species.

\section{References}

van Achterberg, C. 1990: Phylogeny of the subfamilies of the family Braconidae (Hymenoptera: Ichneumonoidea). - Zool. Verh. Leiden 258:1-95.

Gärdenfors, U. 1986: Taxonomic and biological revision of Palearctic Ephedrus Haliday (Hymenoptera: Braconidae, Aphidiinae). - Entomol. Scand., Suppl. 27:195.

Halme, J. 1977: Aphidiidae (Hymenoptera) of Finland. I. Historical review and records of eight new species. Notulae Entomol. 57:109-114.

- 1992: Ephedrus (Ephedrus) koponeni n. sp. from Finland (Hymenoptera, Braconidae, Aphidiinae). Entomol. Fennica 3:113-116.

- 1986: Aphidiidae (Hymenoptera) of Finland. II. Pseudopauesia prunicola gen. n., sp. n., a new parasitoid of Rhopalosiphum padi (L.) (Homoptera: Aphididae). - Ann. Entomol. Fennici 52:20-27.

Heikinheimo, O. 1990: Aphid species and morphs new to the fauna of Finland (Homoptera, Aphididae, Macrosiphini). - Entomol. Fennica 1:65-98.

Huldén, L. \& Heikinheimo, O. 1984: Checklist of Finnish insects. Hemipteroidea. — Notulae Entomol. 64:97124.

Mackauer, M. 1963: Bemerkungen zur Systematik, Verbreitung und Wirtsbindung des Ephedrus persicaeKomplexes (Hymenoptera: Aphidiidae). — Zeitschr. Angew. Entomol. 52:343-354.
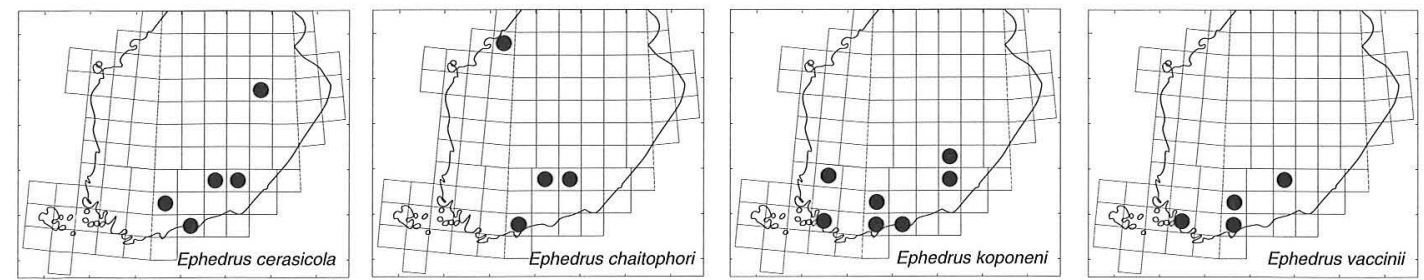

Fig. 3. UTM distribution maps for the Finnish species of Ephedrus and Toxares (continued on next page).
- 1968: Die Aphidiiden Finnlands. — Fauna Fennica 22:1-40

Mackauer, M. \& Starý, P. 1967: Hym. Ichneumonoidea, world Aphidiidae. - In Delucchi, V. \& Remaudière, C. (ed.), Index of entomophagous insects. Paris. 195 pp.

Peltonen, O. 1976: Kesäretki Ruokolahdelle ja Taipalsaarelle 2.-6.VII.1975. — Ann. Entomol. Fennici 42:150151.

Shuja-Uddin 1974: Two new species of the genus Toxares Westwood (Aphidiidae: Hymenoptera) from India with a note on the genus. - Indian J. Entomol. 36:268274.

Starý, P. 1958: A taxonomic revision of some aphidiine genera with remarks on the subfamily Aphidiinae (Hymenoptera: Braconidae). - Sb. Faun. Praci Entomol. Odd. Nar. Mus. Praze 3:53-96.

- 1962: Bionomics and ecology of Ephedrus pulchellus Stelfox an important parasite of leafcurling aphids in Czechoslovakia, with notes on the diapause (Hym., Aphidiidae). — Entomophaga 7:91-100.

- 1970: Biology of aphid parasites (Hymenoptera: Aphidiidae) with respect to integrated control. - The Hague. $643 \mathrm{pp}$.

- 1982: The role of ash (Fraxinus) as a reservoir of aphid parasitoids with description of a new species in Central Europe (Hymenoptera, Aphidiidae). — Acta Entomol. Bohemoslov. 79:97-107.

Starý, P. \& Leclant, F. 1973: Ephedrus blattnyi sp. n. (Hymenoptera, Aphidiidae), a new parasite of Pterocomma ringdahli Wahlgr. from Czechoslovakia. Acta Entomol. Bohemoslovaca 70:269-271.

Takada, H. 1965: A new species of the genus Toxares Haliday from Japan (Hymenoptera: Aphidiidae). Insecta Matsum. 28:17-18.

Thuneberg, E. 1963: Beiträge zur Kenntnis der finnischen Blattläuse (Hom., Aphidoidea) sowie deren Parasiten. III. - Ann. Entomol. Fennici 29:130-134.

Received 4.VI.1991 

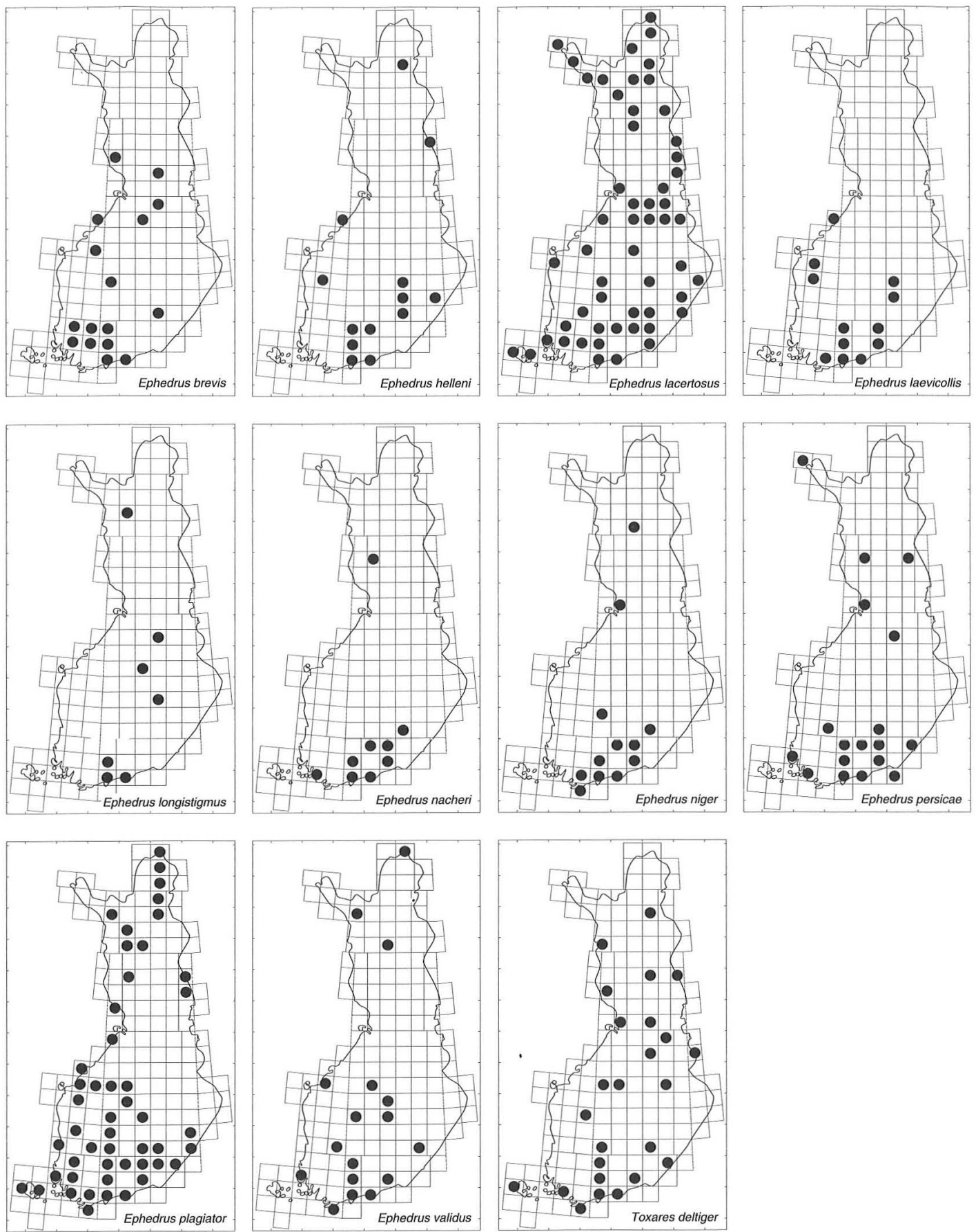

Fig. 3 (continued). UTM distribution maps for the Finnish species of Ephedrus and Toxares. 